\title{
Submarine groundwater discharge to Tampa Bay: Nutrient fluxes and biogeochemistry of the coastal aquifer ${ }^{2}$
}

\author{
Kevin D. Kroeger*, Peter W. Swarzenski, Wm. Jason Greenwood, Christopher Reich \\ US Geological Survey 600 4th Street South St. Petersburg, FL, USA
}

Received 17 June 2006; received in revised form 16 August 2006; accepted 31 October 2006

Available online 10 January 2007

\begin{abstract}
To separately quantify the roles of fresh and saline submarine groundwater discharge (SGD), relative to that of rivers, in transporting nutrients to Tampa Bay, Florida, we used three approaches (Darcy's Law calculations, a watershed water budget, and a ${ }^{222} \mathrm{Rn}$ mass-balance) to estimate rate of SGD from the Pinellas peninsula. Groundwater samples were collected in 69 locations in the coastal aquifer to examine biogeochemical conditions, nutrient concentrations and stoichiometry, and salinity structure. Salinity structure was also examined using stationary electrical resistivity measurements. The coastal aquifer along the Pinellas peninsula was chemically reducing in all locations sampled, and that condition influences nitrogen (N) form and mobility of $\mathrm{N}_{\text {and }} \mathrm{PO}_{4}^{3-}$. Concentrations of $\mathrm{NH}_{4}^{+}, \mathrm{PO}_{4}^{3-}$ and ratio of dissolved inorganic $\mathrm{N}$ (DIN) to $\mathrm{PO}_{4}^{3-}$ were all related to measured oxidation/reduction potential (pe) of the groundwater. Ratio of DIN: $\mathrm{PO}_{4}^{3-}$ was below Redfield ratio in both fresh and saline groundwater. Nitrogen occurred almost exclusively in reduced forms, $\mathrm{NH}_{4}^{+}$and dissolved organic nitrogen (DON), suggesting that anthropogenic $\mathrm{N}$ is exported from the watershed in those forms. In comparison to other SGD studies, rate of $\mathrm{PO}_{4}^{3-}$ flux in the seepage zone $\left(\mu \mathrm{M} \mathrm{m}^{-2} \mathrm{~d}^{-1}\right)$ in Tampa Bay was higher than previous estimates, likely due to 1) high watershed population density, 2) chemically reducing conditions, and 3) high ion concentrations in fresh groundwater. Estimates of freshwater groundwater flux indicate that the ratio of groundwater discharge to stream flow is $\sim 20$ to $50 \%$, and that the magnitudes of both the total dissolved nitrogen and $\mathrm{PO}_{4}^{3-}$ loads due to fresh SGD are $\sim 40$ to $100 \%$ of loads carried by streams. Estimates of SGD based on radon inventories in near-shore waters were 2 to 5 times greater than the estimates of freshwater groundwater discharge, suggesting that brackish and saline SGD is also an important process in Tampa Bay and results in flux of regenerated $\mathrm{N}$ and $\mathrm{P}$ from sediment to surface water.

Published by Elsevier B.V.
\end{abstract}

Keywords: Submarine groundwater discharge; Watershed; Aquifer; Nitrogen; Phosphorus; Oxidation/reduction potential; Dissolved organic nitrogen

\footnotetext{
it Submitted to a special volume of marine chemistry on biogeochemical cycles of Tampa Bay.

* Corresponding author. Present address: US Geological Survey Woods Hole Science Center Woods Hole, MA 02543, USA. Tel.: +1 508457 2270; fax: +1 5084572310 .

E-mail address: kkroeger@usgs.gov (K.D. Kroeger).
}

\section{Introduction}

\subsection{Submarine groundwater discharge}

In watersheds with conductive soils and aquifers and with permeable coastal sediments, groundwater is a major, and in some cases primary, route of transport from land to sea for freshwater and its solutes. In coastal watersheds, a portion of freshwater that flows down- 
gradient from surficial aquifers discharges directly to coastal waters from a seepage face that may be located near the intertidal zone or may extend farther offshore (Thibodeaux and Boyle, 1987; Bokuniewicz, 1992). Such groundwater flow directly into the sea has been referred to as submarine groundwater discharge (SGD). Nutrient concentrations in discharging groundwater are often orders of magnitude higher than in receiving waters. Some portion of nutrient loads deposited to watersheds are carried to aquifers with percolating water, so that nutrient concentrations in groundwater increase with increasing population density on watersheds (Valiela et al., 2000; Nolan and Stoner, 2000; Cole et al., 2006; Kroeger et al., 2006). Primary sources for increasing nutrient loads are wastewater disposal, fertilizer applications, and atmospheric deposition (Valiela et al., 1997). As a result of widespread development of coastal watersheds, eutrophication in coastal waters due to freshwater-transported, non-point source land-derived nutrient loads is a worldwide phenomenon and perhaps the greatest agent of change altering their ecology (Howarth et al., 2000).

In addition to the terrestrially-derived, fresh groundwater and solutes, saline and brackish groundwater are often important components of SGD. Dispersion along the boundary between discharging fresh groundwater and the saline groundwater wedge beneath results in entrainment of saline groundwater prior to discharge, and produces a gradient in groundwater salinity from land to sea. Processes including density-driven flow and tidal pumping create brackish and saline groundwater circulation (Li et al., 1999). Hence, SGD often consists of a substantial amount of recirculating seawater, and thus it might produce substantial fluxes of sedimentregenerated nutrients and other porewater materials to coastal waters (Swarzenski and Baskaran, 2007).

Increasing attention to the phenomenon of SGD, and recent advances in techniques including improved methods for application of radon and radium as naturally-occurring SGD tracers (Cable et al., 1996; Moore, 1996; Burnett and Dulaiova, 2003), have increased the number and quality of SGD estimates. Although there are still large gaps in geographic distribution of observations, compilations of the literature make it clear that SGD is a worldwide phenomenon that on a global scale can rival riverine transport of chemical loads to sea, and that on a regional scale can exceed riverine input of freshwater and/or solutes (Taniguchi et al., 2002; Slomp and Van Cappellen, 2004). Still, relative importance of groundwater and riverine discharges of water and associated chemical loads has only been assessed in a handful of locations
(Taniguchi et al., 2002), and separate quantification of fresh and saline SGD is yet more uncommon. Furthermore, there has been relatively little detailed examination of the biogeochemical conditions and behavior of nutrients in near-shore aquifers and in discharging groundwater. Thus, despite its importance as a source of freshwater and associated materials, SGD remains a poorly-understood and often overlooked process.

Tampa Bay is a subtropical estuary on the west coast of Florida that has been classified as eutrophic (Bricker et al., 1999). Primary production in Tampa Bay is nitrogen limited (Wang et al., 1999). Given the hydrogeological setting in Tampa Bay and its watershed-with sandy soils, conductive aquifers and permeable coastal sediments-groundwater discharge might be an important route for freshwater and nutrient delivery from the watershed. To separately quantify the roles of fresh and saline SGD, relative to that of rivers, in transporting water and nutrients to Tampa Bay, we have used three approaches to estimate rate of SGD from the Pinellas peninsula. Groundwater discharge rate was estimated based on Darcy's Law calculations, on a watershed water budget, and on radon mass-balances for near-shore bay water. Our efforts were focused on the surficial aquifer, rather than the much deeper and larger Floridan aquifer, because the shallow aquifer is in more immediate contact with water recharge from precipitation and with anthropogenic nutrient loads to watersheds, and therefore is likely to contribute greater water and nutrient fluxes to the bay. Since few data exist on biogeochemistry of SGD zones, we have also examined biogeochemical conditions and the chemical species and stoichiometry of the nutrients in the near-shore aquifer.

\section{Methods}

\subsection{Site description}

The Pinellas peninsula occurs within the boundary of Pinellas County, the most densely populated county in Florida, and comprises the western shore of Tampa Bay (Fig. 1). The surface area of the county is $725 \mathrm{~km}^{2}$, and in 2000 it had a population of 921,000 people. Much of the county is sewered, but there is widespread irrigation with tertiary-treated, reclaimed wastewater. In addition, the sewer system is in disrepair, and mingling does occur between sewage and groundwater. The hydrogeologic framework in the Pinellas peninsula is complex, with presence of two distinct freshwater-containing aquifers that in most locations are separated by a thick confining unit (Hutchinson, 1983; Causseaux, 1985). This study 


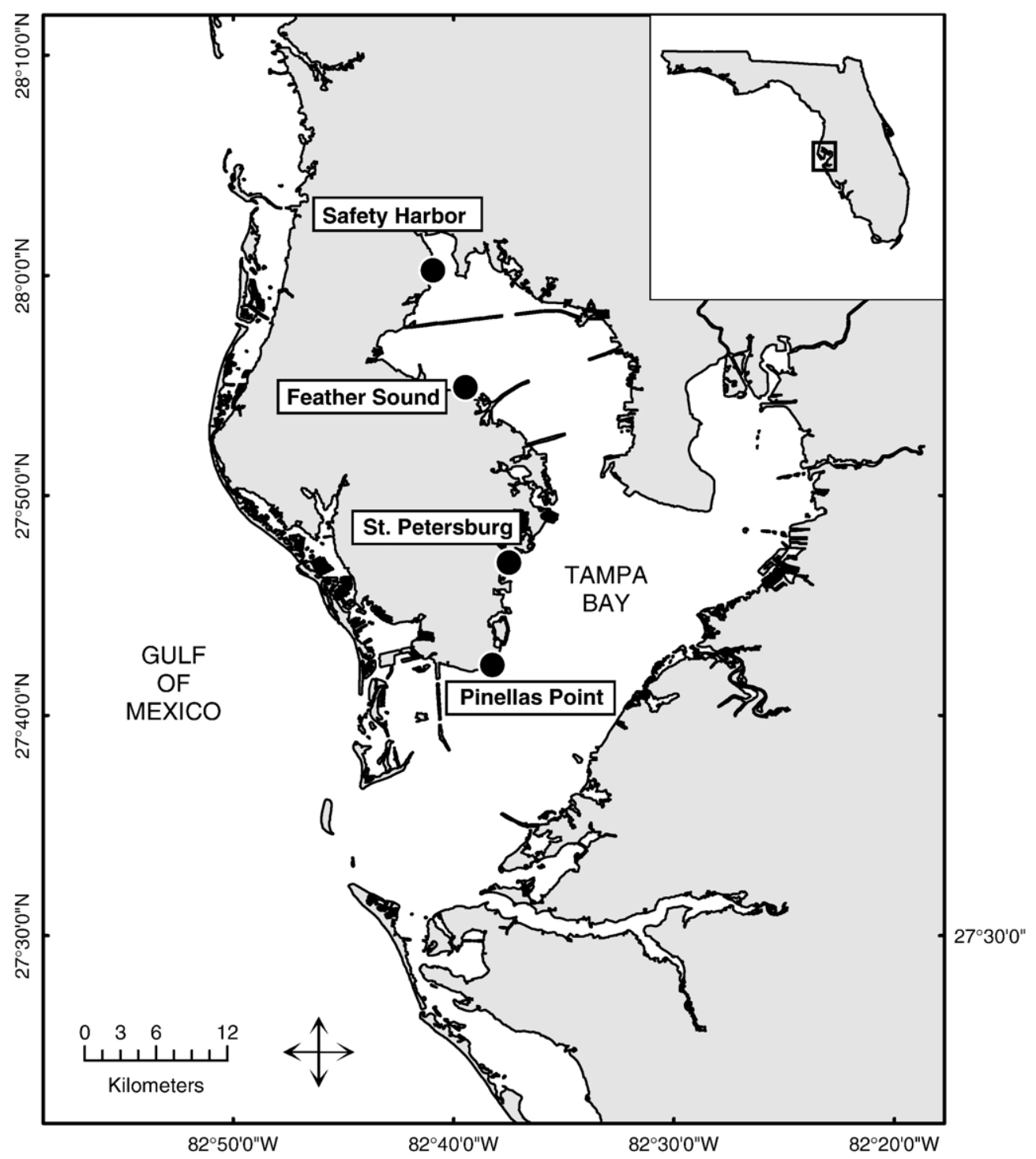

Fig. 1. A map of Tampa Bay with black circles indicating the four study sites included in this study.

focused on the surficial aquifer, which is composed of sands, silts and clays and ranges in thickness from 0 to $28 \mathrm{~m}$. Given the interbedded clay and fine sand that comprises the deeper portions of the surficial aquifer and the thick sequence of multiple clay confining layers that lies between the surficial and Floridan aquifers, horizontal transport within the surficial aquifer should be much more rapid than vertical transport through the clays, and the majority of recharged water is expected to discharge to surface waters rather than recharge the Floridan aquifer. Dominant soils on the peninsula are permeable sands with very low runoff (Lewis et al., 2004), and therefore most rainfall to pervious surfaces that does not evapotranspire is likely to recharge the aquifer. In the Tampa Bay watershed there is a high degree of land cover by impervious surfaces, but much of the runoff from such surfaces is collected into drainage canals and retention ponds that are in direct contact with the aquifer beneath.

\subsection{Groundwater sampling and analyses}

To examine salinity structure, biogeochemical conditions and nutrient concentrations in groundwater within the zone of discharge, we used a piezometer system (AMS, Inc. Idaho, USA; Charette and Allen, 2006) to collect groundwater samples within a few tens of meters landward and seaward of shore at four sites along the 
$56 \mathrm{~km}$ Pinellas peninsula shoreline in Tampa Bay (Fig. 1). At the Feather Sound site, additional samples were collected from 11 shallow wells in an array extending as far as $1.4 \mathrm{~km}$ inland and with screened intervals ranging from 0.6 to $1.5 \mathrm{~m}$. In total, 69 groundwater samples were collected at depths ranging from 0.3 to $6.4 \mathrm{~m}$ below land surface and nutrient concentrations $(\mathrm{N}$, $\mathrm{P}, \mathrm{Si}$ ) were quantified in 62 of those samples (Electronic appendix, doi:10.1016/j.marchem.2006.10.012). Samples were brought to the surface through nylon tubing using a peristaltic pump.

At each sampling depth, several void volumes were pumped and then flow was passed through a flowthough cell with a YSI 600R multi-probe inserted. When readings stabilized for salinity, dissolved oxygen, oxidation/reduction potential, $\mathrm{pH}$, and temperature, we recorded the values and then collected samples. Samples for nutrient concentrations were passed through a Millipore polyethersulfone cartridge filter $(0.45 \mu \mathrm{m}$ pore size), into acid-washed polyethylene sample bottles, and stored on ice until return the laboratory. A replicate nutrient sample for $\mathrm{PO}_{4}^{3-}$ analysis was acidified to $\mathrm{pH} 2$, with $8 \mathrm{~N}$ sulfurous acid, to prevent scavenging by precipitation of iron oxides. Nutrient concentrations $\left(\mathrm{NO}_{3}^{-}+\mathrm{NO}_{2}^{-}, \mathrm{PO}_{4}^{3-}, \mathrm{NH}_{4}^{+}, \mathrm{SiO}_{4}^{4-}\right)$ were analyzed by colorimetric techniques (Lachat QuickChem 8000 autoanalyzer, WHOI Nutrient Analytical Facility). Nitrate and nitrite were not separately quantified, and in this manuscript their sum is referred to as " $\mathrm{NO}_{3}^{- \text {" }}$. Total dissolved nitrogen (TDN) was measured using persulfate digestion (D'Elia et al., 1977). Dissolved organic nitrogen (DON) concentration was calculated as $\mathrm{DON}=\mathrm{TDN}-\mathrm{NO}_{3}^{-}-\mathrm{NH}_{4}^{+}$.

Activity of ${ }^{222} \mathrm{Rn}$ in discrete $250 \mathrm{~mL}$ groundwater samples was measured using RAD7 radon analyzers (Durridge Co., Inc.). Samples were bubbled with air in a closed loop to equilibrate radon in water with radon in gas phase. The gas phase was counted, and radon content of the water was calculated from equilibrium relationship between air and water (Burnett et al., 2001).

\subsection{Resistivity measurements}

To image salinity structure in the coastal aquifer for the purpose of identifying groundwater source and discharge zones, we measured apparent electrical resistivity in a $112 \mathrm{~m}$ long and $28 \mathrm{~m}$ deep, shore-perpendicular transect at the Pinellas Point site. Although subterranean resistivity is influenced by variations in lithology and porosity, it is primarily controlled by interstitial salinity (Manheim et al., 2004; Greenwood et al., 2006). In the present study, resistivity was mea- sured using stationary deployment of a $112 \mathrm{~m}$ long cable with 56 electrodes in a dipole-dipole array coupled to an Advanced Geosciences SuperSting R8 resistivity meter. The resulting data were processed to resolve the best fit layered earth model using EarthImager 2D 2.0.8 software with an iterative least squares smooth model inversion method. Resolution of sharp salinity boundaries was increased by using a starting model where the apparent resistivity pseudo-section was overlain by measured water column resistivity and seabed bathymetry (Greenwood et al., 2006).

\subsection{SGD estimate based on water budget}

To estimate annual rate of fresh groundwater discharge from Pinellas peninsula to Tampa Bay, we used a watershed water budget. The approach assumes that volume of groundwater stored in the watershed is approximately at steady state, so that annual rate of discharge is equal to rate of recharge. Groundwater discharge $(G)$ was calculated as residual precipitation $(P)$ after corrections for evapotranspiration $(E / T)$ and stream flow $(S)$ :

$$
\begin{aligned}
& G\left(\mathrm{~mm} \mathrm{y}^{-1}\right) \\
& \quad=P\left(\mathrm{~mm} \mathrm{y}^{-1}\right)-E / T\left(\mathrm{~mm} \mathrm{y}^{-1}\right)-S\left(\mathrm{~mm} \mathrm{y}^{-1}\right)
\end{aligned}
$$

Since water table elevations in the surficial aquifer are close to land surface throughout the Pinellas peninsula (Causseaux, 1985), we assumed that delineation of the groundwater watershed was similar to that of drainage basins based on topography (from http://gulfsci.usgs.gov/ ims/index.html). Average annual rainfall was from the Southeast Regional Climate Center (http://cirrus.dnr. state.sc.us/cgi-bin/sercc/cliMAIN.pl?fl7886).

Evapotranspiration rate was based on measurements at a nearby site in Pasco County, FL using combined eddy correlation and energy budget methods (A. Swancar, USGS, written comm.). The proportion of annual rainfall that discharges from the watershed as runoff or baseflow to streams was based on analyses of gauged streams that discharge to Tampa Bay (Hutchinson, 1983; Causseaux, 1985). Error in watershed water budgets occurs due to errors in measurement and in regionalization, and we estimated error for our water budget by propagation of typical error rate for each term in Eq. (1) (Winter, 1981).

\subsection{SGD estimate based on Darcy's Law}

To obtain a second estimate of rate of fresh groundwater discharge from the Pinellas peninsula to Tampa Bay, we calculated groundwater velocity $(V)$ and 
discharge rate $(Q)$ based on Darcy's Law (Freeze and Cherry, 1979):

$V=K /$ porosity $\times i$

$Q=K \times A \times i$

$V$ is bulk flow velocity of groundwater in the aquifer $\left(\mathrm{m} \mathrm{d}^{-1}\right), K$ is aquifer hydraulic conductivity $\left(\mathrm{m} \mathrm{d}^{-1}\right), i$ is the hydraulic gradient in the aquifer $\left(\mathrm{m} \mathrm{m}^{-1}\right), Q$ is volume rate of groundwater discharge $\left(\mathrm{m}^{3} \mathrm{~d}^{-1}\right)$, and $A$ is cross-sectional area of the plane perpendicular to flow that is defined by length along shore and thickness of the aquifer. Values for $K$, porosity, hydraulic gradient and aquifer thickness were from Causseaux (1985). For the Darcy calculations, the watershed was divided into four sections, with one of our groundwater sampling sites centered within each section (Fig. 1).

\subsection{SGD estimate based on radon inventories}

We used a ${ }^{222} \mathrm{Rn}$ mass-balance approach at three of the four study sites to estimate rate of SGD to the nearshore surface waters. In coastal waters receiving SGD, groundwater is the primary source for Rn, and methods have been developed to allow calculation of SGD rate based on rate of change in Rn inventory in coastal waters (Cable et al., 1996; Corbett et al., 2000; Burnett and Dulaiova, 2003; Lambert and Burnett, 2003; Crusius et al., 2005). In the present study, we estimated SGD rate using a box model approach to account for known inputs and losses of $\mathrm{Rn}$ and to estimate contribution of SGD to measured temporal changes in

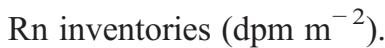

To quantify rates of change in ${ }^{222} \mathrm{Rn}$ concentration and inventory, stationary time-series deployments of RAD7 radon analyzers were carried out. At each site, 3 to 4 analyzers were deployed just offshore, with a bilge pump used to pump surface water through an air/water equilibrator. Air was circulated through the equilibration chamber in a closed loop, and measurements of $\mathrm{Rn}$ in air were collected every $20 \mathrm{~min}$. Surface-water radon activities in bay water offshore of the study sites were measured during mobile deployments of RAD7 radon monitors, using methodology similar to Dulaiova et al. (2005). Diffusion of Rn from sediments is a small term in Rn budgets (Corbett et al., 2000), and we assumed that rate of diffusion from Tampa Bay sediments were equivalent to rate measured by Lambert and Burnett (2003) at a geologically similar study site. Rn activity in discharging groundwater was estimated based on measurements in a series of 50 groundwater samples collected from the 4 sites (see Methods for groundwater collections). Loss of Rn due to atmospheric evasion was estimated using the procedures outlined by Lambert and Burnett (2003).

\section{Results and discussion}

\subsection{Salinity structure and groundwater flow in the coastal aquifer}

There was evidence that the surficial aquifer extends offshore into subtidal sediments of Tampa Bay at each of the 4 study sites examined, based on groundwater collections by piezometer and on electrical resistivity measurements. The resistivity measurement conducted in January 2006 at the Pinellas Point site provides detailed information on sub-surface resistivity, to a depth of $28 \mathrm{~m}$ below land surface in a $112 \mathrm{~m}$ shoreperpendicular transect (Fig. 2). Groundwater collections and salinity measurements conducted in April 2005 along the same transect depicted in Fig. 2, indicate that salinity correlates well with measured resistivity, and suggest that red and yellow areas within Fig. 2 indicate groundwater salinity in the range of 0 to 2 , green indicates low salinity brackish water, and dark blue

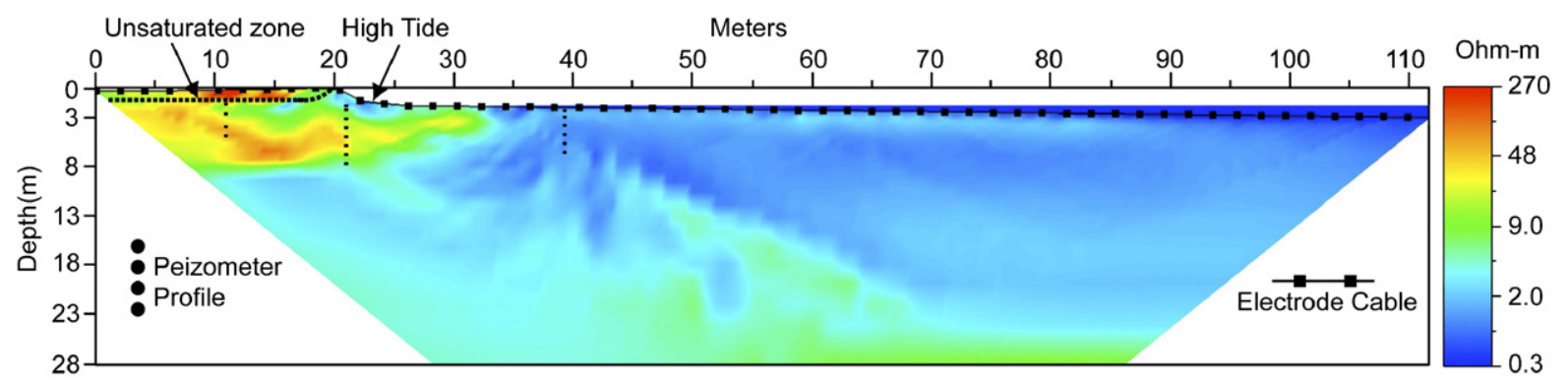

Fig. 2. Stationary resistivity profile in a shore-perpendicular transect at the Pinellas Point site. Red and yellow regions at the left (on-shore) portion of the plot indicate extension into the subtidal zone of the freshwater lens in the shallow portion of the surficial aquifer. Dotted, vertical lines indicate locations at which groundwater samples were collected by piezometer. 
indicates groundwater with salinity approaching that of overlying water $(\sim 30)$.

If resistivity is reflective of salinity throughout the profile (Fig. 2), then the data suggest major transport of fresh groundwater in the shallow portion of the aquifer $(<8 \mathrm{~m}$ below land surface) and that a zone of fresh or low salinity groundwater discharge occurs in the region of $30 \mathrm{~m}$ along the transect ( $<20 \mathrm{~m}$ offshore of high tide). While the saturated thickness of the surficial aquifer in the Pinellas Point area is $\sim 28 \mathrm{~m}$, laboratory analyses of hydraulic conductivity of aquifer material collected at a test site in the northeastern portion of the peninsula indicated that a maximum occurs $\left(55 \mathrm{~m} \mathrm{~d}^{-1}\right)$ at 3 and $7 \mathrm{~m}$ below land surface (Causseaux, 1985). Our own observations during piezometer surveys at the Pinellas Point, St. Petersburg, and Feather Sound sites, and during well drilling at Feather Sound, indicated that a layer of conductive sands typically occurs to a depth of 1 to $8 \mathrm{~m}$ below land surface, followed by a layer with lower hydraulic conductivity consisting of a mixture of sand and clay. In the piezometer transect at the Pinellas Point site, easy penetration and good water flow occurred to a depth of $8 \mathrm{~m}$ (Fig. $2 y$-axis), but deeper penetration was not possible. Those observations, in the context of the resistivity profile, suggest that groundwater velocity and rate of fresh SGD is at a maximum in the low salinity, shallow portion of the aquifer. However, in the resistivity data, brackish zones (green color, Fig. 2) also occur deeper and farther offshore. Those features might be associated with discharge from the deeper, less conductive, portions of the surficial aquifer. At the Pinellas Point site, deployment of a single automated seepage meter from 11 to 14 April, 2005 did, indeed, indicate a moderate rate of SGD $\sim 60 \mathrm{~m}$ offshore (data not shown), suggesting a broader zone of brackish to saline SGD.

\subsection{Biogeochemical conditions and nutrient concentrations}

The coastal groundwater, both fresh and saline, in the surficial aquifer along the Tampa Bay coast of Pinellas county is chemically reducing and anoxic or approaching anoxic in nearly all locations (Table 1, and Electronic appendix). Interestingly, dissolved oxygen concentration and oxidation/reduction potential $(\mathrm{p} \varepsilon)$ were at similar levels in fresh and saline groundwater (Table 1). In contrast, in the near-shore aquifer of Waquoit Bay (Cape Cod, Massachusetts), fresh groundwater is more oxidizing than saline groundwater (Kroeger and Charette, unpublished). Low $p \varepsilon$ and dissolved oxygen concentrations in the Pinellas fresh groundwater might be related to inclusions of reduced
Table 1

Summary statistics (average and standard deviation) for nutrient concentrations in freshwater (salinity <2) and brackish to saline (salinity 2 to 60 ) groundwater samples

\begin{tabular}{|c|c|c|c|c|c|}
\hline & & \multicolumn{2}{|c|}{$\begin{array}{l}\text { Fresh } \\
\text { groundwater }\end{array}$} & \multicolumn{2}{|c|}{$\begin{array}{l}\text { Saline } \\
\text { groundwater }\end{array}$} \\
\hline & & Average & S.D. & Average & S.D. \\
\hline Dissolved $\mathrm{O}_{2}$ & $\left(\mathrm{mg} \mathrm{L}^{-1}\right)$ & 0.54 & 0.57 & 0.49 & 0.90 \\
\hline $\mathrm{p} \varepsilon$ & & 0.69 & 1.93 & 0.21 & 1.63 \\
\hline $\mathrm{SiO}_{4}^{4-}$ & $(\mu \mathrm{M})$ & 143 & 106 & 108 & 75 \\
\hline $\mathrm{PO}_{4}^{3-}$ & $(\mu \mathrm{M})$ & 10 & 11 & 15 & 15 \\
\hline $\mathrm{NO}_{3}^{-}$ & $(\mu \mathrm{M})$ & 15 & 53 & 0 & 0 \\
\hline $\mathrm{NH}_{4}^{+}$ & $(\mu \mathrm{M})$ & 68 & 66 & 37 & 54 \\
\hline DON & $(\mu \mathrm{M})$ & 84 & 60 & 41 & 34 \\
\hline TDN & $(\mu \mathrm{M})$ & 167 & 106 & 79 & 65 \\
\hline $\mathrm{NO}_{3}^{-} / \mathrm{TDN}$ & $(\%)$ & 9 & $\mathrm{n} / \mathrm{a}$ & 0.3 & $\mathrm{n} / \mathrm{a}$ \\
\hline $\mathrm{NH}_{4}^{+} / \mathrm{TDN}$ & $(\%)$ & 41 & $\mathrm{n} / \mathrm{a}$ & 47 & $\mathrm{n} / \mathrm{a}$ \\
\hline DON/TDN & $(\%)$ & 50 & $\mathrm{n} / \mathrm{a}$ & 52 & $\mathrm{n} / \mathrm{a}$ \\
\hline $\mathrm{DIN} / \mathrm{PO}_{4}^{3-}$ & & 8.7 & $\mathrm{n} / \mathrm{a}$ & 2.5 & $\mathrm{n} / \mathrm{a}$ \\
\hline
\end{tabular}

Number of observations $=26$ in freshwater zone and 36 in brackish to saline zone. $\mathrm{N}$ to $\mathrm{P}$ ratios and ratios (percent) of each $\mathrm{N}$ form to total dissolved $\mathrm{N}$ calculated from average values.

materials including organic matter and reduced metal species in the marine sediments that were the origin for the aquifer sediments (Appelo and Postma, 1993). Another feature that might contribute to the reducing conditions in the aquifer is the very shallow water table throughout the watershed. Causseaux (1985) reported dry-season vadose zone thickness (depth to the aquifer) as generally less than $1.5 \mathrm{~m}$ throughout Pinellas county, but ranging from $0 \mathrm{~m}$ in the lowlands to $>3 \mathrm{~m}$ in uplands. In our own observations during this study vadose zone thickness was on average $0.7 \mathrm{~m}$ thick. During the rainy season, elevation of the water table approaches to within a few $\mathrm{cm}$ of, or even exceeds, elevation of the land surface in some locations. The vadose zone is typically a site of intense oxidation of dissolved materials prior to recharge to aquifers, due to high degree of contact between air and percolating water in unsaturated pore-spaces (e.g. DeSimone et al., 1996, Erskine, 2000). The very thin or absent vadose zone in the Pinellas peninsula might result in recharge of groundwater containing more reduced species and lower oxygen concentration. In Cape Cod watersheds, dissolved organic carbon (Pabich et al., 2001) and DON (Kroeger et al., 2006) concentrations in groundwater are highest in watersheds with thinnest vadose zones. As we discuss below, the reducing conditions in the Pinellas aquifer likely have a strong influence on chemical form, concentration and mobility of $\mathrm{P}$ and $\mathrm{N}$. Measured oxidation/reduction potential ( $\mathrm{p} \varepsilon$ ) was a good qualitative predictor of the balance between the $\mathrm{NH}_{4}^{+} / \mathrm{NO}_{3}^{-}$redox couple and of $\mathrm{P}$ concentration and $\mathrm{N}: \mathrm{P}$ ratio. 


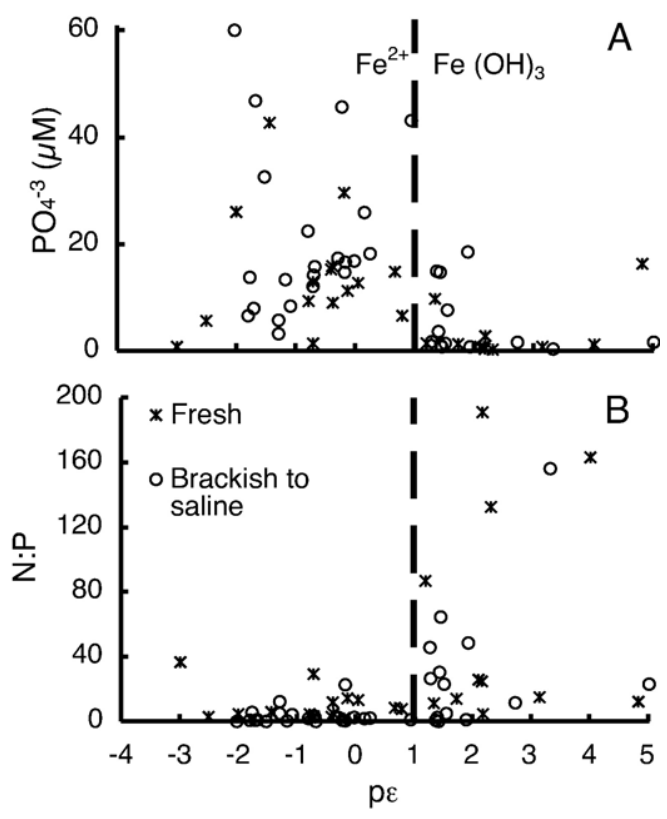

Fig. 3. (A) $\mathrm{PO}_{4}^{3-}$ concentration and (B) $\mathrm{DIN}: \mathrm{PO}_{4}^{3-}$ vs. measured $\mathrm{p} \varepsilon$ in fresh and brackish to saline groundwater samples collected along the shore of Pinellas peninsula. Vertical dashed line represents thermodynamic stability limit at $\mathrm{pH} 7$ for $\mathrm{Fe}^{2+}$ with respect to amorphous $\mathrm{Fe}$ $(\mathrm{OH})_{3}$ (from Stumm and Morgan, 1996). Average $\mathrm{pH}$ was 6.93 for freshwater samples and 7.04 for brackish to saline samples.

Phosphate concentration in both fresh and saline groundwater was higher than average concentration in U.S. groundwaters of $6 \mu \mathrm{M}$ (Nolan and Stoner, 1995). Relatively high $\mathrm{PO}_{4}^{3-}$ concentration in Pinellas groundwater is likely related to 1) high watershed population density, 2) reducing conditions in the aquifer, and 3) acidification of samples upon collection to prevent scavenging of $\mathrm{PO}_{4}^{3-}$ by precipitation of Fe oxide. With regard to acidification of samples, a comparison of measured $\mathrm{PO}_{4}^{3-}$ concentration in acidified and un-acidified aliquots indicated that on average $26 \%$ of the $\mathrm{PO}_{4}^{3-}$ had been scavenged from solution in the un-acidified samples. In samples with very high $\mathrm{Fe}^{2+}$ concentration, complete removal of $\mathrm{PO}_{4}^{3-}$ can occur (M. Charette, pers. comm.). Those observations suggest that protocols for measurement of $\mathrm{PO}_{4}^{3-}$ in reducing groundwater samples should include acidification upon collection.

Ratio of average $\mathrm{N}$ to average $\mathrm{P}$ was well below the Redfield ratio of 16:1 in both fresh and saline groundwater (Table 1), and therefore SGD should maintain N-limitation for primary production in Tampa Bay. Much higher N:P ratios are commonly reported in fresh groundwater, typically ranging in the literature from 18 to $10^{3}$, though $\mathrm{N}: \mathrm{P}$ below Redfield has been observed previously (summarized by Slomp and Van Cappellen, 2004). High
$\mathrm{N}: \mathrm{P}$ ratios commonly occur in fresh groundwater due to affinity of $\mathrm{PO}_{4}^{3-}$ for typically abundant $\mathrm{Fe}$ oxides or $\mathrm{Ca}$ minerals in aquifer sediments (Griffieon, 1994; Charette and Sholkovitz, 2002; Slomp and Van Cappellen, 2004). However, under sufficiently reducing conditions, reductive dissolution of $\mathrm{Fe}$ will liberate $\mathrm{P}$ into solution. In the present study, both $\mathrm{PO}_{4}^{3-}$ concentrations and $\mathrm{N}: \mathrm{P}$ ratios in fresh and saline groundwater were related to $\mathrm{p} \varepsilon$, with generally higher $\mathrm{P}$ concentrations and lower N:P at lower $\mathrm{p} \varepsilon$ values (Fig. 3). The transitions from high to low $\mathrm{P}$ concentration and from low to high $\mathrm{N}: \mathrm{P}$ ratio occur in the region of the equilibrium constant for transition between $\mathrm{Fe}^{+}$and $\mathrm{Fe}(\mathrm{OH}) \mathrm{am}$. Such a result supports the notion that Fe oxidation state has strong influence on $\mathrm{P}$ concentration and $\mathrm{N}: \mathrm{P}$ ratio in the aquifer and that generally low $\mathrm{N}: \mathrm{P}$ ratios occurring in the Pinellas aquifer are related to reducing conditions.

Average concentrations of major fixed $\mathrm{N}$ forms and of TDN were higher by a factor of roughly 2 in fresh groundwater than in brackish to saline groundwater, but the composition (mix of $\mathrm{NO}_{3}^{-}, \mathrm{NH}_{4}^{+}, \mathrm{DON}$ ) of TDN in the two zones was similar, with DON comprising about half of the TDN and with $\mathrm{NH}_{4}^{+}$dominating the DIN (Table 1). $\mathrm{NO}_{3}^{-}$was absent from brackish/saline groundwater, and occurred at concentrations greater than $\sim 1 \mu \mathrm{M}$ in only two fresh groundwater samples (Electronic appendix, doi:10.1016/j.marchem.2006.10.012). Similar N species composition also occurs farther inland within the surficial aquifer (Fernandez and Barr, 1984). Below we discuss relationships of $\mathrm{N}$ form to measured $\mathrm{p} \varepsilon$, and discuss possible DON and ammonium sources.

A likely explanation for occurrence of DIN primarily as $\mathrm{NH}_{4}^{+}$is low pe throughout the aquifer (Fig. 4). As shown in Fig. 4, all measured observations of $p \varepsilon$ were

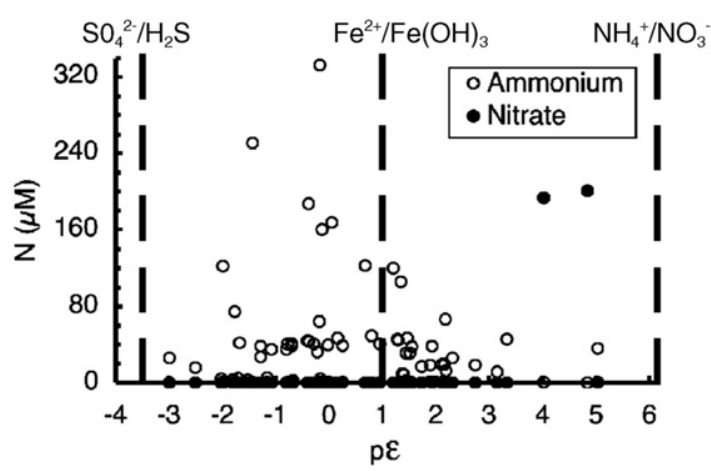

Fig. 4. Nitrate and ammonium concentrations vs. measured $\mathrm{p} \varepsilon$ in fresh, brackish and saline groundwater samples collected along the shore of Pinellas peninsula. Vertical dashed lines represent thermodynamic stability limits at $\mathrm{pH} 7$ for some redox couples that are likely actively cycled in the aquifer (from Stumm and Morgan, 1996). Average $\mathrm{pH}$ was 6.93 for freshwater samples and 7.04 for brackish to saline samples. 
within the thermodynamic stability limits for $\mathrm{NH}_{4}^{+}$ (Stumm and Morgan, 1996). At lower $\mathrm{p} \varepsilon$, ammonium concentrations spanned a wider range and highest concentrations occurred, while at higher $\mathrm{p} \varepsilon$ ammonium concentrations were low. Co-occurrence of nitrate and ammonium was not observed at concentrations greater than $\sim 1 \mu \mathrm{M}$. Concentration of $\mathrm{NO}_{3}^{-}$in the two $\mathrm{NO}_{3}^{-}$ dominated samples was high $(\sim 200 \mu \mathrm{M})$, and both occurred at relatively high measured pe (Fig. 4). Thus, $\mathrm{NH}_{4}^{+}$appears to be thermodynamically stable within both fresh and saline portions of the aquifer. Since saline groundwater is equivalent to porewater of the estuarine sediment, the source for dissolved $\mathrm{N}$ must be remineralization within the sediments and the resulting $\mathrm{NH}_{4}^{+}$and DON has had little or no exposure to oxygen. In the freshwater portion of the aquifer, it is not clear whether $\mathrm{N}$ is recharged to the aquifer primarily as $\mathrm{NH}_{4}^{+}$and DON, or whether $\mathrm{NO}_{3}^{-}$that is recharged to the aquifer is then rapidly reduced by microbial processes to ammonium (dissimilatory nitrate reduction to ammonium) or $\mathrm{N}_{2}$ gas (denitrification) or to organic $\mathrm{N}$ (assimilation or adsorption to humic material). DON might be produced within the aquifer due to microbial activity under conditions of high DIN concentration, or, as a result of the thin vadose zone throughout the Pinellas peninsula, a high rate of DON flux from the watershed surface to the aquifer might occur (Kroeger et al., 2006).

Mobility of $\mathrm{NH}_{4}^{+}$in aquifers is largely controlled by competitive cation exchange on clays (at low to neutral $\mathrm{pH})$ and to $\mathrm{Fe}$ and $\mathrm{Mn}$ oxyhydroxides at $\mathrm{pH}>$ neutral (Sverjensky and Sahai, 1996; Buss et al., 2004). Ion concentration within the freshwater portion of the aquifer is generally high. For instance, in a well screened at $3.6 \mathrm{~m}$ below land surface and located $1.4 \mathrm{~km}$ inland at the Feather Sound site, groundwater salinity (measured as conductivity) was 1.4 (see Appendix, sample FS11-1). Minimum recorded salinity among the samples collected for this study was 0.17 . Specific conductance in a series of 13 well samples located $3.5 \mathrm{~km}$ inland on the Pinellas peninsula averaged $1600 \mu \mathrm{s} / \mathrm{cm}$ (equivalent to $\sim 0.8$ salinity) (Fernandez and Barr, 1984). Therefore, high concentrations of $\mathrm{NH}_{4}^{+}$in solution and mobility within the aquifer might be maintained by high cation concentration and/or by low availability of Fe and Mn oxyhydroxide sorption sites associated with reducing conditions in the aquifer.

Occurrence of high concentrations of $\mathrm{NH}_{4}^{+}$and DON, and near absence of $\mathrm{NO}_{3}^{-}$, throughout the freshwater aquifer in a densely-populated, urban watershed where substantial anthropogenic $\mathrm{N}$ sources exist, suggests that anthropogenic $\mathrm{N}$ in the Pinellas aquifer occurs largely and $\mathrm{NH}_{4}^{+}$and DON. Similarly, in a study of 10 Cape Cod
(Massachusetts) watersheds, subdivided into 43 watershed segments, DON comprised on average $>60 \%$ of TDN concentration in near-shore groundwater (Kroeger et al., 2006). Furthermore DON concentration in the Cape Cod groundwater increased significantly with increasing population density on the watersheds, suggesting that a substantial portion of the DON is of wastewater or other anthropogenic origin. The observed composition of dissolved $\mathrm{N}$ species in the present study is perhaps unexpected in fresh groundwater from an urban aquifer because examination of literature relating to $\mathrm{N}$ biogeochemistry of watersheds and of groundwater would suggest that human activities result in increasing introduction of $\mathrm{NO}_{3}^{-}$to aquifers (Nolan and Stoner, 2000, Burkart and Stoner, 2002; Cole et al., 2006). Ammonium and DON do occur at significant concentrations in close proximity to large sources such as landfills or wastewater disposal sites, but $\mathrm{NO}_{3}^{-}$is often the dominant form in aquifers because, while $\mathrm{NO}_{3}^{-}$is mobile in soils, concentrations of $\mathrm{NH}_{4}^{+}$and dissolved organic matter are attenuated by nitrification, mineralization and sorption to metal oxides or clays during transport through vadose zones and aquifers (Freeze and Cherry, 1979; Cronan and Aiken, 1985; Wilhelm et al., 1994; Stumm and Morgan, 1996; DeSimone et al., 1997; Erskine, 2000; Pabich et al., 2001; Slomp and Van Cappellen, 2004; Buss et al., 2004).

Furthermore, DON is generally considered to be from natural sources rather than anthropogenic sources, since forested watersheds often export primarily DON in streams (Perakis and Hedin, 2002). Perhaps due in part to those findings and impressions, and to legal regulation of $\mathrm{NO}_{3}^{-}$concentrations in drinking water, study of $\mathrm{N}$ in groundwater has focused heavily on $\mathrm{NO}_{3}^{-}$, to the partial exclusion of the other $\mathrm{N}$ species. As a result, the concept that anthropogenic $\mathrm{N}$ in aquifers occurs as $\mathrm{NO}_{3}^{-}$, which is accurate in many aquifers, has been over-generalized such that groundwater loading of reduced $\mathrm{N}$ forms $\left(\mathrm{NH}_{4}^{+}\right.$ and DON) commonly are not considered at all in groundwater monitoring efforts, in watershed nutrient loading models or in management plans — including those for Tampa Bay (Poe et al., 2003). Therefore, dominance of groundwater $\mathrm{N}$ concentrations by DON and $\mathrm{NH}_{4}^{+}$in coastal watersheds with land uses ranging from forested to dense residential and urban (Kroeger et al., 2006, this study) is an important observation.

\subsection{Rate of fresh groundwater discharge}

Based on the watershed water budget, rate of SGD directly to the bay is estimated to be $2.9 \mathrm{~m}^{3} \mathrm{~d}^{-1}$ per $\mathrm{m}$ of shoreline, or $\sim 50 \%$ of the rate of stream flow to the bay 
Table 2

Calculations of groundwater discharge from the surficial aquifer based on a water budget (Eq. (1))

\begin{tabular}{lll}
\hline & & \pm Error \\
\hline Rainfall $\left(\mathrm{mm} \mathrm{y}^{-1}\right)$ & 1332 & 230 \\
Watershed area $\left(\mathrm{m}^{2}\right)$ & $3.7 \times 10^{8}$ & \\
Evapotranspiration $\left(\mathrm{mm} \mathrm{y}^{-1}\right)$ & 850 & 153 \\
Stream flow (runoff) $\left(\mathrm{mm} \mathrm{y}^{-1}\right)$ & 160 & 14 \\
Stream flow (baseflow) $\left(\mathrm{mm} \mathrm{y}^{-1}\right)$ & 160 & 14 \\
Groundwater discharge to bay $\left(\mathrm{mm} \mathrm{y}^{-1}\right)$ & 162 & 277 \\
Stream discharge $\left(\mathrm{m}^{3} \mathrm{y}^{-1}\right)$ & $1.2 \times 10^{8}$ & $1.1 \times 10^{7}$ \\
Groundwater discharge $\left(\mathrm{m}^{3} \mathrm{y}^{-1}\right)$ & $6.0 \times 10^{7}$ & $1.0 \times 10^{8}$ \\
Groundwater discharge & 2.9 & 5.0 \\
$\quad\left(\mathrm{~m}^{3} \mathrm{~d}^{-1}\right.$ per m shoreline) & & \\
\hline
\end{tabular}

Data sources are given in Section 2.4 of the text. Units for error are same as units for each term.

(Table 2). Estimates of groundwater velocity, based on Darcy's Law, suggest bulk groundwater flow rate in the aquifer ranging from 0.2 to $0.7 \mathrm{~m} \mathrm{~d}^{-1}$ and provides a somewhat smaller estimated SGD rate of $1.2 \mathrm{~m}^{3} \mathrm{~d}^{-1}$ per $\mathrm{m}$ of shoreline (Table 3). The difference between estimated rates of groundwater discharge based on the water budget and Darcy's Law might be related to 1) recharge from the surficial to the Floridan aquifer, 2) groundwater discharge to portions of streams downstream of USGS gauging stations, or 3) error inherent in both of the estimates.

The water budget assumes that discharge from the surficial aquifer is equal to recharge and calculates recharge to the aquifer based on difference between rainfall and other water losses from the watershed. Some unknown portion of the water recharged to the surficial aquifer likely does seep through the clay layer that occurs between the surficial and Floridan aquifer. Using Darcy's Law calculations, Hutchinson (1983) estimated rate of SGD to Tampa Bay from the Floridan aquifer beneath Pinellas peninsula to be $6 \times 10^{6} \mathrm{~m}^{3} \mathrm{y}^{-1}$, or about $10 \%$ of our estimated rate of recharge to the surficial aquifer.

\subsection{Rate of total SGD based on radon inventories}

Results of the continuous radon measurements in near-shore surface waters of Tampa Bay provide support for occurrence of SGD along the Pinellas peninsula shore and at rates that are within an order of magnitude of estimated rate of fresh groundwater discharge. Since elevated radon activities typically occur in groundwater/ porewater of all salinities (e.g., Abraham et al., 2003), radon inventories in surface waters are reflective of any groundwater advection through sediments (Burnett and Dulaiova, 2003). In the present study, radon activity in groundwater was not related to salinity (Swarzenski et al., 2007) in 50 groundwater samples collected along the Tampa Bay shore. Thus, the rates of SGD calculated based on radon inventories are estimates of total SGD (fresh, brackish and saline groundwater discharges).

Modeled estimates of SGD rate based on continuous radon measurements are based on radon inventories $\left(\mathrm{dpm} \mathrm{m}^{-2}\right)$, and thus seepage rates are calculated in units of $\mathrm{cm} \mathrm{d}^{-1}$. To estimate volume of discharge per unit time, we need an estimate of the surface area of the seepage zone. As discussed previously, fresh groundwater discharge from the shallow, most conductive portion of the surficial aquifer likely occurs within the first $\sim 10$ to $20 \mathrm{~m}$ offshore, and SGD occurring farther offshore must be brackish or saline discharge. At the Pinellas Point site, a seepage meter deployed $54 \mathrm{~m}$ offshore recorded moderate seepage rates. Furthermore, there is evidence for circulation of reduced salinity groundwater at least as far offshore as $54 \mathrm{~m}$ (Fig. 2). To allow calculation of SGD volume, we used $54 \mathrm{~m}$ as a minimum estimate of the width of the seepage zone for fresh and saline SGD. To the extent that we have underestimated the width of the seepage face, we have underestimated the rate of total SGD.

Average Rn activity in groundwater varied considerably among the three sites, from 421 to $3222 \mathrm{dpm} \mathrm{L}^{-1}$ (Table 4). In the time-series at Pinellas Point, Rn activity

Table 3

Calculations of groundwater discharge from the surficial aquifer based on Darcy's Law (Eqs. (2) and (3))

\begin{tabular}{llllll}
\hline & Safety harbor & Feather sound & St. Petersburg & Pinellas Point & Pinellas peninsula (whole) \\
\hline Head gradient (i) & $7.8 \times 10^{-3}$ & $2.5 \times 10^{-3}$ & $4.6 \times 10^{-3}$ & $2.4 \times 10^{-3}$ & \\
$\mathrm{~K}\left(\mathrm{~m} \mathrm{~d}^{-1}\right)$ & 27.8 & 27.8 & 27.8 & 27.8 \\
Porosity & 0.33 & 0.33 & 0.33 & 0.33 \\
Aquifer thickness $(\mathrm{m})$ & 7.6 & 7.6 & 15.2 & 15.2 \\
Transmissivity $\left(\mathrm{m}^{2} \mathrm{~d}^{-1}\right)$ & 211 & 211 & 423 & 423 & \\
Velocity $\left(\mathrm{m} \mathrm{d}^{-1}\right)$ & 0.7 & 0.2 & 0.4 & 0.2 & 56.7 \\
Length of shoreline $(\mathrm{km})$ & 13.3 & 19.1 & 13.2 & 11.2 & $2.5 \times 10^{7}$ \\
Discharge $\left(\mathrm{m}^{3} \mathrm{y}^{-1}\right)$ & $8.0 \times 10^{6}$ & $3.7 \times 10^{6}$ & $9.3 \times 10^{6}$ & $4.1 \times 10^{6}$ & 1.2 \\
Discharge $\left(\mathrm{m}^{3} \mathrm{~d}^{-1}\right.$ per m shoreline) & 1.6 & 0.5 & 1.9 & 1.0 & \\
\hline
\end{tabular}


Table 4

Estimated total SGD rates (freshwater + saline) based on the Rn model

\begin{tabular}{|c|c|c|c|c|c|}
\hline & Safety Harbor & Feather Sound & St. Petersburg & Pinellas Point & Pinellas Peninsula \\
\hline Groundwater average $\mathrm{Rn}\left(\mathrm{dpm} \mathrm{L} \mathrm{L}^{-1}\right)$ & 3222 & 1697 & 441 & 421 & \\
\hline Offshore average $\mathrm{Rn}\left(\mathrm{dpm} \mathrm{L} \mathrm{L}^{-1}\right)$ & 5.7 & 9.5 & 8 & 6.9 & \\
\hline Study site average $\mathrm{Rn}\left(\mathrm{dpm} \mathrm{L} \mathrm{L}^{-1}\right)$ & 15.9 & n.d. & 20.3 & 10.1 & \\
\hline \multicolumn{6}{|l|}{ Total SGD, Rn (fresh + saline) } \\
\hline$\left(\mathrm{cm} \mathrm{d}^{-1}\right)$ & 1.6 & n.d. & 24.3 & 5.0 & 10.3 \\
\hline$\left(\mathrm{m}^{3} \mathrm{y}^{-1}\right)$ & $4.4 \times 10^{6}$ & n.d. & $6.3 \times 10^{7}$ & $1.1 \times 10^{7}$ & $1.2 \times 10^{8}$ \\
\hline$\left(\mathrm{m}^{3} \mathrm{~d}^{-1} \mathrm{~m}^{-1}\right.$ shoreline $)$ & 0.9 & n.d. & 13.1 & 2.7 & 5.6 \\
\hline Fresh SGD, Darcy's Law ( $\mathrm{m}^{3} \mathrm{~d}^{-1} \mathrm{~m}^{-1}$ shoreline) & 1.6 & 0.5 & 1.9 & 1.0 & 1.2 \\
\hline Fresh SGD, water budget $\left(\mathrm{m}^{3} \mathrm{~d}^{-1} \mathrm{~m}^{-1}\right.$ shoreline) & & & & & 2.9 \\
\hline Saline SGD, Total — Fresh $\left(\mathrm{m}^{3} \mathrm{~d}^{-1} \mathrm{~m}^{-1}\right.$ shoreline $)$ & & & & & 2.7 to 4.4 \\
\hline Fresh SGD:Total SGD (\%) & & & & & 22 to 52 \\
\hline Fresh SGD:Stream flow (\%) & & & & & 21 to 50 \\
\hline
\end{tabular}

Comparisons are made to estimates of fresh SGD rate based on Darcy's Law and to fresh SGD rate and stream discharge rate based on the water budget. Saline SGD is calculated as difference between total and fresh SGD.

in surface water ranged from 5 to $15 \mathrm{dpm} \mathrm{L} \mathrm{L}^{-1}$ (Fig. 5A). $\mathrm{Rn}$ concentration was influenced both by tide and by wind speed, so that maxima occurred when low wind speeds coincided with low tide (Fig. 5A and B). Based on rates of change in radon inventory $\left(\mathrm{dpm} \mathrm{m}^{-2}\right)$, modeled rate of total SGD at Pinellas Point ranged from 2.5 to $7 \mathrm{~cm} \mathrm{~d}^{-1}$ during April 21 to 24, 2005 (Fig. 5B). Rate of total SGD at the three sites along the $56 \mathrm{~km}$ coastline ranged widely, from 1.6 to $24 \mathrm{~cm} \mathrm{~d}^{-1}$ (Table 4). At Pinellas Point and St. Petersburg, total SGD rate based on radon inventories was greater, by a factor of $\sim 3$ to 7 , than rate of fresh groundwater discharge based on Darcy's Law calculations, while at Safety Harbor, rate of SGD based on radon inventories was $\sim 50 \%$ of the rate based on the Darcy's Law calculations (Table 4). Thus, the high degree of variability among sites in rate of total SGD based on radon inventories is not reflected in spatially averaged groundwater discharge rate estimates based on Darcy's Law (Table 3). The radon model is sensitive to measured radon activity in the groundwater endmember (Corbett et al., 2000), and the relatively low SGD rate estimate based on the radon model at the Safety Harbor site is related in part to the high groundwater radon activity at that site. Thus, the variability among sites in groundwater radon activity highlights both the importance of obtaining local information on groundwater radon activity for this type of study and a source of error in the method due to the difficulty in knowing the true radon activity of discharging groundwater.

If we assume that average measured rate of total SGD $\left(10 \mathrm{~cm} \mathrm{~d}^{-1}\right)$ occurs in a $54 \mathrm{~m}$ wide seepage face along the Tampa Bay coast of the Pinellas peninsula, we obtain an estimated SGD rate of $5.6 \mathrm{~m}^{3} \mathrm{~d}^{-1}$ per $\mathrm{m}$ of shoreline (Table 4). That rate is well within the range of estimates at other Gulf coast sites (Cable et al., 1997; Burnett et al., 2002), and is close to the average rate of SGD in Tampa Bay $\left(6 \mathrm{~m}^{3} \mathrm{~d}^{-1}\right.$ per $\mathrm{m}$ shoreline) based on a radium mass-balance (Swarzenski et al., 2007).

Since we have independent estimates of fresh groundwater discharge, we calculated saline groundwater discharge rate based on difference between total SGD (from radon inventories) and fresh groundwater discharge (from water budget and Darcy's Law calculations). That calculation suggests that fresh groundwater accounts for $\sim 20$ to $50 \%$ of total SGD (Table 4). In a similar study in Waquoit Bay, Massachusetts, estimated fresh SGD rate (calculated
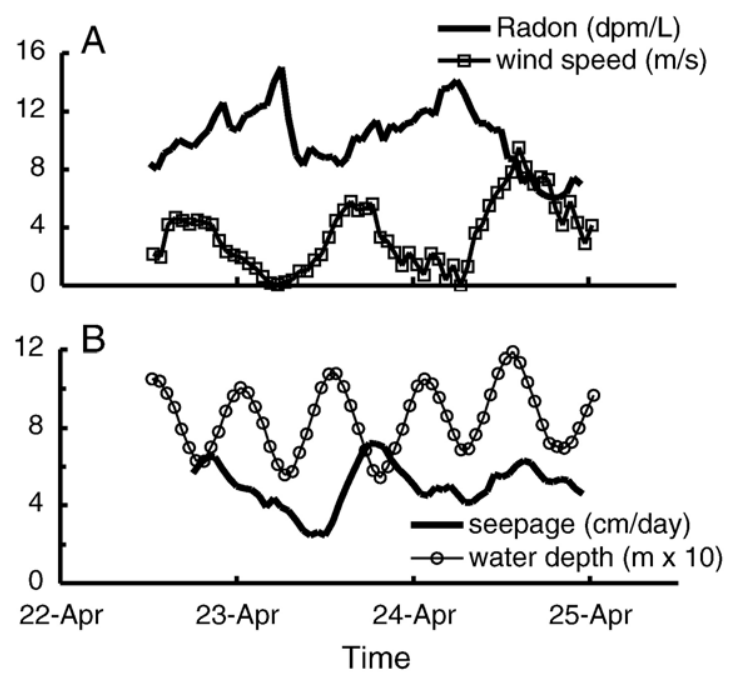

Fig. 5. Results of the 3-day stationary deployment of RAD7 radon analyzers at the Pinellas Point site. Depicted are (A) radon activity and wind speed, and (B) water depth and modeled groundwater seepage rate. 
Table 5

Nutrient loads (mol per year) from Pinellas peninsula to Tampa Bay due to discharge of fresh and saline groundwater and to stream discharge

\begin{tabular}{|c|c|c|c|c|c|c|}
\hline & & \multicolumn{2}{|c|}{ Fresh SGD } & \multicolumn{3}{|l|}{ Saline SGD } \\
\hline & & Darcy & Water budget & $\mathrm{Rn}$ - water budget & Rn - Darcy & Stream load \\
\hline \multirow[t]{2}{*}{$\mathrm{SiO}_{4}^{4-}$} & $\left(\mathrm{mol} \mathrm{y}^{-1}\right)$ & $3.6 \times 10^{6}$ & $8.6 \times 10^{6}$ & $5.9 \times 10^{6}$ & $9.5 \times 10^{6}$ & n.d. \\
\hline & $\left(\mathrm{mol} \mathrm{y}^{-1}\right)$ & $2.4 \times 10^{5}$ & $5.7 \times 10^{5}$ & $8.1 \times 10^{5}$ & $1.3 \times 10^{6}$ & $5.8 \times 10^{5}$ \\
\hline $\mathrm{PO}_{4}^{3-}$ & SGD:Stream (\%) & 41 & 99 & 139 & 223 & \\
\hline $\mathrm{NO}_{3}^{-}$ & $\left(\mathrm{mol} \mathrm{y}^{-1}\right)$ & $3.9 \times 10^{5}$ & $9.2 \times 10^{5}$ & $1.4 \times 10^{4}$ & $2.2 \times 10^{4}$ & n.d. \\
\hline $\mathrm{NH}_{4}^{+}$ & $\left(\mathrm{mol} \mathrm{y}^{-1}\right)$ & $1.7 \times 10^{6}$ & $4.1 \times 10^{6}$ & $2.0 \times 10^{6}$ & $3.3 \times 10^{6}$ & n.d. \\
\hline \multirow[t]{2}{*}{ DON } & $\left(\mathrm{mol} \mathrm{y}^{-1}\right)$ & $2.1 \times 10^{6}$ & $5.0 \times 10^{6}$ & $2.3 \times 10^{6}$ & $3.6 \times 10^{6}$ & n.d. \\
\hline & $\left(\mathrm{mol} \mathrm{y}^{-1}\right)$ & $4.2 \times 10^{6}$ & $1.0 \times 10^{7}$ & $4.3 \times 10^{6}$ & $6.9 \times 10^{6}$ & $9.9 \times 10^{6}$ \\
\hline TDN & SGD:Stream (\%) & 43 & 102 & 44 & 70 & \\
\hline
\end{tabular}

Calculations are based on nutrient concentrations in fresh and brackish to saline groundwater (Table 1) and on estimated annual volumes of water discharge (Tables 2, 3 and 4). Nutrient concentrations in stream water (4.9 $\mu \mathrm{M} \mathrm{PO}_{4}^{3-} ; 83 \mu \mathrm{M}$ TDN) from Flock et al. (2005).

by Darcy's Law) was $\sim 70 \%$ of total SGD rate based on radon inventories (Mulligan and Charette, 2006). In a bay-wide examination of SGD in Tampa Bay based on a radium isotope mass-balance, Swarzenski et al. (this volume) estimated that saline SGD accounts for $\sim 90 \%$ of total SGD.

\subsection{Nutrient loading estimates}

To calculate rates of nutrient loading $(\mathrm{Si}, \mathrm{N}, \mathrm{P})$ to Tampa Bay resulting from SGD along the $57 \mathrm{~km}$ Pinellas peninsula coast (Table 5), we multiplied estimated fresh and saline SGD rates (Tables 2, 3 and 4) by average nutrient concentrations in fresh and brackish/saline groundwater (Table 1). Rates of P and $\mathrm{N}$ loading due to SGD were compared to loads from stream discharge.

To calculate stream loads, we multiplied annual stream discharge rate from the water budget (Table 2) by average $\mathrm{PO}_{4}^{3-}$ and TDN concentrations in streams

Table 6

Comparison to nutrient loading estimates in the literature

\begin{tabular}{cll}
\hline & $\begin{array}{l}\text { Flux, total SGD per } \\
\text { area of seepage zone } \\
\left(\mu \mathrm{M} \mathrm{m}^{-2} \mathrm{~d}^{-1}\right)\end{array}$ & $\begin{array}{l}\text { Yield, fresh SGD } \\
\text { per area of watershed } \\
\left(\mathrm{mol} \mathrm{km} \mathrm{y}^{-1}\right)\end{array}$ \\
\hline $\mathrm{PO}_{4}^{3-}$ & & \\
This study & 1235 & \\
Literature & 0.58 to 900 & $2.7 \times 10^{4}$ \\
TDN & & $1.3 \times 10^{4}$ to $1.2 \times 10^{5}$ \\
This study & 12,815 & \\
Literature & 160 to 72,000 &
\end{tabular}

Literature values for flux rates of $\mathrm{N}$ and $\mathrm{P}$ in the seepage zone are the global range of observations reported in the literature and compiled by Slomp and Van Cappellen (2004). Literature values for fresh SGDtransported TDN yield per $\mathrm{km}^{-2}$ of watershed are based on water budgets for 10 Cape Cod, Massachusetts watersheds, and rates are calculated from Kroeger et al. (2006).
(Flock et al., 2005). Results indicate that magnitude of both $\mathrm{P}$ and $\mathrm{N}$ loads to the bay due to fresh SGD are $\sim 40$ to $100 \%$ of the loads due to stream discharge (Table 5). Saline SGD results in flux of regenerated $\mathrm{N}$ from sediment to surface water at a rate similar to rate of $\mathrm{N}$ loading due to fresh SGD. Rate of regenerated $\mathrm{P}$ flux due to saline SGD is estimated to be $\sim 2$ to 3 times greater than $\mathrm{P}$ loading rate due to fresh SGD.

In comparison to other $\mathrm{SGD}$ studies, rate of $\mathrm{PO}_{4}^{3-}$ flux in the seepage zone $\left(\mu \mathrm{M} \mathrm{m}^{-2} \mathrm{~d}^{-1}\right)$ was higher than previous estimates compiled by Slomp and Van Cappellen (2004) (Table 6). As discussed previously, high rate of $\mathrm{PO}_{4}^{3-}$ flux from the Pinellas peninsula is likely related to both high population density on the watershed and chemically reducing conditions within the aquifer.

Estimated rate of TDN flux per area of seepage zone falls within the range of previous estimates (Table 6). Estimates of TDN flux rates per area of seepage zone range in the literature by a factor of $\sim 450$. Such large variability might be related in part to small-scale variability in both $\mathrm{N}$ concentrations in groundwater and SGD rate. A more productive unit, in terms of examinations of general controls on SGD, for expressing SGD and associated nutrient flux rates might be one that links the fluxes to the contributing watershed and that normalizes to the area of the watershed. For instance, if we view fresh SGD-transported TDN loads, for 10 Cape Cod watersheds and the Tampa Bay watershed, in terms of yield per area of contributing watershed $\left(\mathrm{mol} \mathrm{km} \mathrm{k}^{-2} \mathrm{y}^{-}\right)$, the range of estimated rates varies by only a factor of 10 (Table 6), despite a wide range in population density on the examined watersheds from 0 to 1270 people $\mathrm{km}^{-2}$. If the set of watersheds examined were to include watersheds that were very distinct from the Cape Cod and west-central Florida watersheds in terms of land uses, hydrogeology, or 
climate, then the range of estimated SGD and TDN yield rates would be expected to increase. Such a result would be conducive to examination of what must be the primary controls on rate of fresh SGD and associated nutrient fluxes.

\section{Conclusions}

Results presented suggest that water and nutrient fluxes due to SGD from Pinellas peninsula to Tampa Bay are substantial relative fluxes carried by rivers. Given the magnitude of the TDN and $\mathrm{PO}_{4}^{3-}$ loads due to SGD, both examination and focused management are warranted of sources of nutrient loads to the aquifers and of mobility and transformations within the aquifer.

The surficial aquifer in Pinellas County is chemically reducing and is anoxic or approaching anoxic in nearly all locations. As a result, dissolved fixed $\mathrm{N}$ occurs primarily as $\mathrm{NH}_{4}^{+}$and $\mathrm{DON}$, and $\mathrm{PO}_{4}^{3-}$ concentrations are relatively high. Ratio of average DIN to average $\mathrm{PO}_{4}^{3-}$ was well below Redfield ratio in both fresh and saline groundwater, and therefore SGD should maintain Nlimitation for primary production in Tampa Bay. Low $\mathrm{p} \varepsilon$ and dissolved oxygen concentrations might be related to inclusions of reduced materials such as pyrite in the marine-source sediments comprising the aquifer and/or to the thin vadose zone throughout the watershed. High concentrations in the groundwater of $\mathrm{NH}_{4}^{+}$and $\mathrm{DON}$, and near-absence of $\mathrm{NO}_{3}^{-}$, in an urban watershed context suggest that anthropogenic $\mathrm{N}$ occurs largely in chemically reduced form. Therefore all forms should be considered in watershed and groundwater $\mathrm{N}$ loading studies, models, and management plans. The question remains as to whether in some settings reduced $\mathrm{N}$ is carried to the aquifer in quantity, perhaps due to occurrence of thin vadose zones, or whether $\mathrm{NO}_{3}^{-}$that percolates to the aquifer is subsequently reduced to $\mathrm{NH}_{4}^{+}$, organic $\mathrm{N}$, or $\mathrm{N} 2$ gas.

\section{Acknowledgments}

This work was supported by a USGS Mendenhall Postdoctoral Fellowship to K.D.K. and by the USGS Coastal and Marine Geology Program's (CMGP) Tampa Bay Project. We thank M. Flock and K. Hammer Levy of the Pinellas County DEM for access their data on nutrient concentrations in streams, and we thank $\mathrm{C}$. Putnam of the City of Largo for providing access to monitoring wells. B. Blake-Collins, C. Stringer and B. Lewelling aided with fieldwork and analyses. P. Henderson conducted nutrient analyses. The comments of M. Baskaran and two anonymous reviewers im- proved the manuscript. The use of trade names is for descriptive purposes only and does not imply endorsement by the U.S. Government.

\section{Appendix A. Supplementary data}

Supplementary data associated with this article can be found, in the online version, at doi:10.1016/ j.marchem.2006.10.012.

\section{References}

Abraham, D.M., Charette, M.A., Allen, M.C., Rago, A., Kroeger, K.D., 2003. Radiochemical estimates of submarine groundwater discharge to Waquoit Bay, Massachusetts. Biological Bulletin 205, 245-248.

Appelo, C.A.J., Postma, D., 1993. Geochemistry, Groundwater and Pollution. Balkema, Rotterdam. 526 pp.

Bokuniewicz, H.J., 1992. Analytical descriptions of subaqueous groundwater seepage. Estuaries 15, 458-464.

Bricker, S., Clement, C.G., Pirhalla, D.E., Orlando, S.P., Farrow, D.R.G., 1999. National estuarine eutrophication assessment: effects of nutrient enrichment in the nation's estuaries. NOAA, National Ocean Service, Special Projects Office and the National Centers for Coastal Ocean Science. Silver Spring, MD. 71 pp.

Burkart, M.R., Stoner, J.D., 2002. Nitrate in aquifers beneath agricultural systems. Water Science and Technology 45, 19-28.

Burnett, W.C., Dulaiova, H., 2003. Estimating the dynamics of groundwater input into the coastal zone via continuous radon-222 measurements. Journal of Environmental Radioactivity 69, 21-35.

Burnett, W.C., Kim, G., Lane-Smith, D., 2001. A continuous radon monitor for assessment of radon in coastal ocean waters. Journal of Radioanalytical and Nuclear Chemistry 249, 167-172.

Burnett, W.C., Chanton, J., Christoff, J., Kontar, E., Krupa, S., Lambert, M., Moore, W., O’Rourke, D., Paulsen, R., Smith, C., Smith, L., Taniguchi, M., 2002. Assessing methodologies for measuring groundwater discharge to the ocean. EOS 83, 117-123.

Buss, S.R., Herbert, A.W., Morgan, P., Thornton, S.F., Smith, J.W.N., 2004. A review of ammonium attenuation in soil and groundwater. Quarterly Journal of Engineering Geology and Hydrogeology 37, 347-359.

Cable, J.E., Burnett, W.C., Chanton, J.P., Weatherly, G.L., 1996. Estimating groundwater discharge into the northeastern Gulf of Mexico using radon-222. Earth and Planetary Science Letters 144, 591-604.

Cable, J.E., Burnett, W.C., Chanton, J.P., 1997. Magnitudes and variations of groundwater seepage into shallow waters of the Gulf of Mexico. Biogeochemistry 38, 189-205.

Causseaux, K.W., 1985. The surficial aquifer in Pinellas County, Florida. USGS Water-Resources Investigations Report, vol. 84-4289.

Charette, M.A., Allen, M.C., 2006. Precision ground water sampling in coastal aquifers using a direct-push, shielded screen well-point system. Ground Water Monitoring \& Remediation 26, 87-93.

Charette, M.A., Sholkovitz, E.R., 2002. Oxidative precipitation of groundwater-derived ferrous iron in the subterranean estuary of a coastal bay. Geophysical Research Letters 29. doi:10.1029/ 2001GL014512.

Cole, M.L., Kroeger, K.D., McClelland, J.W., Valiela, I., 2006. Effects of watershed land use on nitrogen concentrations and $\delta^{15} \mathrm{~N}$ in groundwater. Biogeochemistry 77, 199-215. 
Corbett, D.R., Dillon, K., Burnett, W., Chanton, J., 2000. Estimating the groundwater contribution into Florida Bay via natural tracers ${ }^{222} \mathrm{Rn}$ and $\mathrm{CH}_{4}$. Limnology and Oceanography 45, 1546-1557.

Cronan, C.S., Aiken, G.R., 1985. Chemistry and transport of soluble humic substances in forested watersheds of the Adirondack Park, New York. Geochimica et Cosmochimica Acta 49, 1697-1705.

Crusius, J., Koopmans, D., Bratton, J., Charette, M.A., Kroeger, K.D., Ryckman, L., Halloran, K., Colman, J., 2005. Submarine groundwater discharge to a small estuary estimated from radon and salinity measurements and a box model. Biogeosciences Discussions 2, 1-35.

D’Elia, C.F., Steudler, P.A., Corwin, N., 1977. Determination of total nitrogen in aqueous samples using persulfate digestion. Limnology and Oceanography 22, 760-764.

DeSimone, L.A., Barlow, P.M., Howes, B.L., 1996. A Nitrogen-Rich Septage-Effluent Plume in a Glacial Aquifer, Cape Cod, Massachusetts, February 1990 through December 1992. Rep. Open-File Report, vol. 95-290. U.S. Geological Survey, Marlborough, MA.

DeSimone, L.A., Howes, B.L., Barlow, P.M., 1997. Mass-balance analysis of reactive transport and cation exchange in a plume of wastewatercontaminated groundwater. Journal of Hydrology 203, 228-249.

Dulaiova, H., Peterson, R., Burnett, W.C., Lane-Smith, D., 2005. A multi-detector continuous monitor for assessment of ${ }^{222} \mathrm{Rn}$ in the coastal ocean. Journal of Radioanalytical and Nuclear Chemistry $263,361-365$.

Erskine, A.D., 2000. Transport of ammonium in aquifers: retardation and degradation. Quarterly Journal of Engineering Geology and Hydrogeology 33, 161-170.

Fernandez, M., Barr, G.L., 1984. Chemical quality of landfill leachate in treatment ponds and migration of leachate in the surficial aquifer, Pinellas County, Florida. Water-Resources Investigations Report, vol. 83-4193.

Flock, M., Deitche, S.M, Hammer Levy, K., Meyer, C., 2005. Ambient monitoring program annual report 2003-2004. Draft Report of the Water Resources Management Section, Pinellas County Department of Environmental Management.

Freeze, R.A., Cherry, J.A., 1979. Groundwater. Prentice Hall. 604 pp.

Greenwood, W.J., Kruse, S., Swarzenski, P.W., 2006. Extending electromagnetic methods to map coastal pore water salinities. Ground Water 44, 292-299.

Griffieon, J., 1994. Uptake of phosphate by iron hydroxides during seepage in relation to development of groundwater composition in coastal areas. Environmental Science \& Technology 28, 675-681.

Howarth, R.W., Anderson, D., Cloern, J., Elfring, C., Hopkinson, C., Lapointe, B., Malone, T., Marcus, N., McGlathery, K., Sharpley, A., Walker, D., 2000. Nutrient pollution of coastal rivers, bays, and seas. Issues in Ecology 7.

Hutchinson, C.B., 1983. Assessment of the interconnection between Tampa Bay and the Floridan Aquifer, Florida. USGS WaterResources Investigations, vol. 82-54.

Kroeger, K.D., Cole, M.L., Valiela, I., 2006. Groundwater-transported dissolved organic nitrogen exports from coastal watersheds. Limnology and Oceanography 51, 2248-2261.

Lambert, M.J., Burnett, W.C., 2003. Submarine groundwater discharge estimates at a Florida coastal site based on continuous radon measurements. Biogeochemistry 66, 55-73.

Lewis, D., Ford, R., Liudahl, K., Vega, J., 2004. Soil Survey of Pinellas County, Florida. Natural Resources Conservation Service, United States Department of Agriculture.

Li, L., Barry, D.A., Stagnitti, F., Parlange, J.U., 1999. Submarine groundwater discharge and associated chemical input into a coastal sea. Water Resources Research 35, 3253-3259.
Manheim, F.T., Krantz, D.E., Bratton, J.F., 2004. Studying ground water under Delmarva coastal bays using electrical resistivity. Ground Water 42, 1052-1068.

Moore, W.S., 1996. Large groundwater inputs to coastal waters revealed by ${ }^{226} \mathrm{Ra}$ enrichments. Nature $380,612-614$.

Mulligan, A.E., Charette, M.A., 2006. Intercomparison of submarine ground water discharge estimates from a sandy unconfined aquifer. Journal of Hydrology 327, 411-425.

Nolan, B.T., Stoner, J.D., 1995. Nutrients in groundwaters of the conterminous United States 1992-1995. Environmental Science and Technology 34, 1156-1165.

Nolan, B.T., Stoner, J.D., 2000. Nutrients in ground waters of the conterminous United States, 1992-1995. Environmental Science \& Technology 34, 1156-1165.

Pabich, W.J., Valiela, I., Hemond, H.F., 2001. Relationship between DOC concentration and vadose zone thickness and depth below water table in groundwater of Cape Cod, U.S.A. Biogeochemistry $55,247-268$.

Perakis, S.S., Hedin, L.O., 2002. Nitrogen loss from unpolluted South American forests mainly via dissolved organic compounds. Nature $415,416-419$.

Poe, A., Hackett, K., Janicki, S., Pribble, R., Janicki, A., 2003. Estimates of total nitrogen, total phosphorus, total suspended solids, and biogeochemical oxygen demand loadings to Tampa Bay, Florida: 1999-2003. Draft Report, Prepared for Tampa Bay Estuary Program.

Slomp, C.P., Van Cappellen, P., 2004. Nutrient inputs to the coastal ocean through submarine groundwater discharge: controls and potential impact. Journal of Hydrology 295, 64-86.

Stumm, W., Morgan, J.J., 1996. Aquatic Chemistry: Chemical Equilibria and Rates in Natural Waters, 3rd edition. John Wiley and Sons, NY. 1022 pp.

Sverjensky, D.A., Sahai, N., 1996. Theoretical prediction of single-site surface protonation equilibrium constants or oxides and silicates in water. Geochimica et Cosmochimica Acta 60, 3773-3797.

Swarzenski, P.W., Baskaran, M., 2007. Uranium distributions in the coastal waters and pore waters of Tampa Bay, Florida. Marine Chemistry 104, 43-57.

Swarzenski, P.W., Reich, C., Kroeger, K.D., Baskaran, M. this volume. $\mathrm{Ra}$ and $\mathrm{Rn}$ isotopes as natural tracers of submarine groundwater discharge in Tampa Bay, FL. Mar. Chem.

Taniguchi, M., Burnett, W.C., Cable, J.E., Turner, J.V., 2002. Investigations of submarine groundwater discharge. Hydrological Processes 16, 2115-2129.

Thibodeaux, L.J., Boyle, J.D., 1987. Bedform-generated convective transport in bottom sediment. Nature 325, 341-343.

Valiela, I., Collins, G., Kremer, J., Lajtha, K., Geist, M., Seely, B., Brawley, J., Sham, C.H., 1997. Nitrogen loading from coastal waters to receiving estuaries: new method and application. Ecological Applications 7, 358-380.

Valiela, I., Geist, M., McClelland, J., Tomasky, G., 2000. Nitrogen loading from watersheds to estuaries: verification of the Waquoit Bay nitrogen loading model. Biogeochemistry 49, 277-293.

Wang, P.F., Martin, J., Morrison, G., 1999. Water quality and eutrophication in Tampa Bay, Florida. Estuarine, Coastal and Shelf Science 49, 1-20.

Wilhelm, S.R., Schiff, S.L., Cherry, J.A., 1994. Biogeochemical evolution of domestic waste water in septic systems: 1. Conceptual model. Ground Water 32, 905-916.

Winter, T.C., 1981. Uncertainties in estimating the water balance of lakes. Water Resources Bulletin 17, 82-115. 